\title{
Timing of Antiretroviral Therapy Initiation Determines Rectal Natural Killer Cell Populations
}

\author{
Netanya S. Utay,, ${ }^{1, \star}$ Karen J. Vigil, ${ }^{2, \star}$ Anoma Somasunderam, ${ }^{1}$ Paula C. Aulicino, ${ }^{3}$ Beverly Smulevitz, ${ }^{4}$ \\ Simbo Chiadika, ${ }^{4}$ David S. Wolf, ${ }^{5}$ Jason T. Kimata, ${ }^{6}$ and Roberto C. Arduino ${ }^{2}$
}

\begin{abstract}
Despite antiretroviral therapy (ART), innate and adaptive immunologic damage persists in the periphery and gut. T memory stem cells (Tscm) and natural killer (NK) cells are pivotal for host defense. Tscm are memory cells capable of antigen response and self-renewal, and circulating and gut NK cell populations may facilitate HIV control. The impact of early ART on circulating and gut Tscm and NK cells is unknown. We enrolled participants who initiated ART during acute versus chronic HIV-1 infection versus no ART in chronic infection. We performed flow cytometry to identify $\mathrm{NK}$ and Tscm cells in the blood and rectum and polymerase chain reaction to quantify the HIV-1 reservoir in both sites. We used the Mann-Whitney $U$-test and Spearman correlation coefficients for analysis. Participants who started ART in acute infection had lower rectal CD56 ${ }^{\text {bright }}$ CD16 ${ }^{\mathrm{dim}}$ cell frequencies than participants who started ART in chronic HIV-1 infection and lower CD56 $6^{\text {bright }}$ and CD56 ${ }^{\text {bright }} \mathrm{CD} 16^{-}$cell frequencies than participants with chronic infection without ART. Higher circulating $\mathrm{NK}$ cell, $\mathrm{CD} 56^{-} \mathrm{CD} 16^{\text {bright }}, \mathrm{CD} 56^{\mathrm{dim}}$, and $\mathrm{CD} 56^{\mathrm{dim}} \mathrm{CD} 16^{\text {bright }}$ frequencies correlated with higher HIV-1 DNA levels in rectal $\mathrm{CD}^{+} \mathrm{T}$ cells, whereas higher circulating $\mathrm{CD} 4^{+} \mathrm{T}$ cell counts correlated with higher rectal NK, CD56 ${ }^{\text {bright }} \mathrm{CD} 16^{\mathrm{dim}}$, and $\mathrm{CD} 56^{\mathrm{dim}} \mathrm{CD} 16^{\text {bright }}$ frequencies. Peripheral CD56 ${ }^{\text {bright }} \mathrm{CD} 16^{-}$cells were inversely associated with rectal $\mathrm{CD} 56^{-} \mathrm{CD} 16^{\text {bright }}$ cells. Rectal $\mathrm{CD} 8^{+} \mathrm{Tscm}$ frequencies were higher in participants without ART than participants with chronic infection on ART. Timing of ART initiation determines rectal NK cell populations, and ART may influence rectal Tscm populations. Whether the gut reservoir contributes to NK cell activation requires further study.
\end{abstract}

Keywords: NK cells, Tscm, HIV, acute HIV, gut

\section{Introduction}

$\mathbf{H}$ IV-1-INDUCED IMMUNOLOGICAL destruction begins during acute infection and is not completely restored in people with HIV-1 initiating antiretroviral therapy (ART) during chronic infection. However, the initiation of ART during acute infection may delay disease progression, preserve adaptive immune function, decrease viral diversity, and reduce the viral reservoir size in blood and mucosa. ${ }^{1,2}$ What is less clear from these studies is the effect that early ART may have on innate immunity, which also responds to HIV-1 infection.

$\mathrm{T}$ memory stem cells (Tscm) are memory cells that are capable of self-renewal ${ }^{3}$ and differentiate into central and effector memory cells. ${ }^{4}$ They can respond to antigen and proliferate rapidly and produce cytokines. ${ }^{3}$ They are found in significantly lower levels in the rectum compared with the peripheral blood. ${ }^{4} \mathrm{CD} 4^{+}$Tscm serve as a reservoir for HIV-1 and are decreased in viremic nonprogressors. As these

\footnotetext{
${ }^{1}$ Division of General Medicine, Department of Internal Medicine, McGovern Medical School, UT Health Science Center at Houston, Houston, Texas.

${ }^{2}$ Division of Infectious Diseases, Department of Internal Medicine, McGovern Medical School, UT Health Science Center at Houston, Houston, Texas.

${ }^{3}$ Laboratorio de Biología Celular y Retrovirus, Hospital de Pediatría “Juan P. Garrahan”-CONICET, Buenos Aires, Argentina.

${ }^{4}$ Division of Cardiology, Department of Internal Medicine, McGovern Medical School, UT Health Science Center at Houston, Houston, Texas.

${ }^{5}$ The Medical Clinic of Houston, LLP, Houston, Texas.

${ }^{6}$ Department of Molecular Virology and Microbiology, Baylor College of Medicine, Houston, Texas.

*These authors contributed equally to this work.
} 
are self-renewing cells with a long half-life, they likely contribute to HIV-1 persistence. ${ }^{3} \mathrm{CD} 8{ }^{+}$Tscm tend to produce interferon gamma (IFN- $\gamma$ ) and interleukin-2, persist in the absence of antigen, and are less susceptible to apoptosis than other memory cells. ${ }^{4}$ Moreover, higher frequencies of $\mathrm{CD}^{+}$ Tscm have been associated with lower plasma HIV-1 RNA levels and less immune activation. ${ }^{5}$

Natural killer (NK) cells are distributed throughout the body and comprise CD56 ${ }^{\mathrm{dim}}\left(\mathrm{CD} 16^{+}\right.$or $\left.\mathrm{CD} 16^{-}\right)$cells, which are cytotoxic; $\mathrm{CD} 56^{\text {bright }}$ cells, which produce cytokines, and have homing receptors, permitting trafficking into tissues; and $\mathrm{CD}^{-} 6^{-}$, which are dysfunctional, with impaired cytotoxicity and cytokine production, and have been shown to abound in the setting of AIDS. ${ }^{6-8}$ Circulating NK cells increase in acute HIV-1 infection with increases in CD56 $6^{\mathrm{dim}}$ and decreases in CD56 $^{\text {bright }}$ subsets. ${ }^{9}$ Circulating CD $56^{-} \mathrm{CD}_{16}{ }^{+} \mathrm{NK}$ cells increase with persistent viral replication. All these changes are reversible with ART. ${ }^{9,10}$ NK cells are also found in the intraepithelial compartments and lamina propria of the gastrointestinal tract. ${ }^{11}$ Gut-associated lymphoid tissue NK cells have been shown to increase as viral load decreases with ART. ${ }^{11}$ Of note, NK cells, particularly CD $56^{\text {bright }}$ NK cells, accumulate within atherosclerotic lesions ${ }^{12}$ and people with unstable coronary artery disease have fewer CD56 ${ }^{\text {dim }}$ NK cells. ${ }^{13}$ CD56 ${ }^{\text {bright }}$ NK cells may contribute to atherosclerosis through IFN- $\gamma$ production, which can promote matrix metalloproteinase secretion and smooth muscle breakdown. ${ }^{13}$ As people with HIV have increased risk of cardiovascular disease, ${ }^{14}$ understanding the evolution of NK cell populations during HIV-1 infection is particularly relevant.

We previously showed that rhesus macaques treated with IFN- $\alpha 2$ a, starting before SIVmac251 inoculation until 4 weeks postinfection, required a greater number of challenges to become infected than placebo animals. ${ }^{15}$ The treated macaques exhibited higher frequency of circulating $\mathrm{CD}^{2} 6^{+} \mathrm{NK}$ cells at the time of challenge, and higher frequency of circulating $\mathrm{CD} 56^{+} \mathrm{NK}$ cells predicted that a greater number of challenges would be needed to transmit infection. Ultimately, these animals became resistant to IFN before acquisition and had larger viral reservoirs. These animals subsequently had a higher frequency of rectal CD16 ${ }^{+}$NK cells 4 weeks after challenge compared with placebo animals. During chronic infection, IFN-treated animals had fewer circulating CD16 ${ }^{+} \mathrm{NK}$ cells and accelerated loss of $\mathrm{CD}^{+} \mathrm{T}$ cells compared with placebo animals.

Thus, as people who initiate ART in acute HIV-1 infection have smaller HIV-1 reservoirs, ${ }^{16}$ we hypothesized people who initiate ART in acute HIV-1 infection would have more peripheral $\mathrm{CD}_{16} 6^{+} \mathrm{NK}$ cells and $\mathrm{CD} 8^{+} \mathrm{Tscm}$ and fewer $\mathrm{CD} 4^{+}$ Tscm and $\mathrm{CD} 16^{+} \mathrm{NK}$ cells in the rectal mucosa. To test this hypothesis, we compared the effects of initiating ART during acute versus chronic HIV-1 infection versus no ART in chronic infection on NK and Tscm cells and the HIV-1 reservoir in blood and rectal mucosa.

\section{Materials and Methods}

This study was approved by the Committee for the Protection of Human Subjects (CPHS), the institutional review board at UTHealth. All participants provided written informed consent before initiating study procedures.

\section{Study design}

Participants with chronic HIV-1 infection and $\mathrm{CD} 4^{+} \mathrm{T}$ cell counts $>500$ cells $/ \mathrm{mm}^{3}$ were recruited in three groups: (1) on ART, started during acute infection, with HIV-1 RNA $<50$ copies/mL; (2) on ART, started during chronic infection, with HIV-1 RNA $<50$ copies/mL; and (3) not on ART, in chronic infection, with HIV-1 RNA $\geq 1,000$ copies $/ \mathrm{mL}$. Acute infection was defined as detectable HIV-1 RNA or p24 antigen in serum or plasma in the setting of a negative or indeterminate HIV antibody test result. Participants with proctitis or other anorectal sexually transmitted infections including active anal herpes simplex virus infection were excluded. All participants underwent phlebotomy and sigmoidoscopy for rectal biopsies.

\section{Carotid intima media thickness}

Subclinical carotid atherosclerosis was evaluated with a Philips IE33 ultrasound system (Amsterdam, the Netherlands). Left and right carotid arteries were imaged from three different angles, and carotid plaque presence was determined by examining the carotid bulb, its bifurcation, the carotid branch arteries, and the common carotid arteries. Carotid wall thickness was measured using the semi-automated carotid analyzer software (Medical Imaging Applications, Coralville, IA). Measurements were made at the R wave of the electrocardiogram on a minimum of two clips on each side and the results were averaged. Carotid plaque was defined as an area of wall thickening that was $\geq 75$ th percentile for age and gender or $>50 \%$ of the thickness of the surrounding wall. The technician was certified by the University of Wisconsin Atherosclerosis Imaging Research Program.

\section{Specimen processing}

Peripheral blood mononuclear cells (PBMCs) were isolated from whole blood using Ficoll density centrifugation. Rectal biopsy samples were placed in RPMI with $10 \%$ fetal bovine serum and transported on wet ice. Cells were extracted from rectal samples using digestion with Liberase TM research grade (Roche, Basel, Switzerland) and filtered using $70 \mu \mathrm{m}$ cell strainers.

\section{Flow cytometry}

Flow cytometry was performed on cells from both peripheral blood and rectal samples. Samples were stained with Aqua LIVE/DEAD ${ }^{\circledR}$ Fixable Dead Cell Stain (Invitrogen, Carlsbad, CA) and the following antibodies: CD3 APC-H7, CCR7 PE-Cy7, CD95 PE-Cy5, CD27 PE, CD16 V450 (All BD Biosciences, San Jose, CA); CD4 BV510 (Biolegend, San Diego, CA); CD8 Qdot655, CD56 PE-Cy5.5 (Invitrogen); and CD45RO ECD (Beckman Coulter, Brea, CA). Cells were sorted using a BD Aria, and LIVE/DEAD ${ }^{-} \mathrm{CD}^{+} \mathrm{CD}^{+} \mathrm{CD} 8^{-} \mathrm{T}$ cells were collected for HIV-1 DNA measurement. Data were analyzed using FlowJo (v.10.2 for Mac OS X).

The frequency of Tscm within the live $\mathrm{CD}^{+} \mathrm{CD} 4^{+}$or live $\mathrm{CD}^{+} \mathrm{CD}^{+}$population was identified by $\mathrm{CD} 45 \mathrm{RO}^{-} \mathrm{CCR} 7^{+}$ $\mathrm{CD} 27^{+} \mathrm{CD} 95^{+} \cdot{ }^{+1} \mathrm{NK}$ cells were identified as live $\mathrm{CD} 3^{-} \mathrm{CD} 4^{-}$ cells within the lymphocyte population (based on size and scatter) that expressed CD56 and/or CD16. Gating scheme and fluorescence minus one are given in Supplementary 
Figures S1 and S2, respectively. For the PBMCs, a median of $1,000,000$ (range $=843,177-1,000,000)$ events were collected with median viability by DAPI of $98.7 \%$ (range $=$ $95.4 \%-99 \%)$. For the rectal samples, median of 834,000 (range $=260,829-1,226,678)$ events were collected, with median viability by DAPI of $91.3 \%$ (range $=84.5 \%-95.6 \%)$.

\section{Quantification of HIV-1 DNA by real-time polymerase chain reaction}

Genomic DNA was isolated from sorted cells using the DNAeasy Blood and Tissue Extraction kit (Qiagen, Hilden, Germany). Quantity of viral DNA in cells of participants was determined by quantitative real-time polymerase chain reaction (PCR) using an ABI One-Step Plus Cycler and a modified protocol of Chun et al. with the described primers (5'-GGTCT CTCTGGTTAGACCAGAT-3' [5'-primer] and 5'-CTGCTAG AGATTTTCCACACTG-3' $3^{\prime} 3^{\prime}$-primer] $)$ and probe (5'-6FAMAGTAGTGTGTGCCCGTCTGTT-TAMRA-3') for amplification of an HIV-1 LTR sequence. ${ }^{18}$ Each $20 \mu \mathrm{L}$ reaction contained $900 \mathrm{nM}$ of each primer and $250 \mathrm{nM}$ of probe, and $1 \times$ TaqMan Gene Expression Master Mix (Applied Biosystems, Foster City, CA), participant-derived DNA sample, HIV containing standard, or no template control. DNA input was quantified by amplification of RNAseP using the TaqMan Copy Number Reference Assay (VIC-TAMRA; Applied Biosystems). PCR conditions consisted of an initial step at $95^{\circ} \mathrm{C}$ for $10 \mathrm{~min}$. This step was followed by 40 cycles of $15 \mathrm{~s}$ at $95^{\circ} \mathrm{C}$ and $1 \mathrm{~min}$ at $60^{\circ} \mathrm{C}$. Tenfold serially diluted ACH-2 DNA over a 6-log range were used to generate standard curves for detection of the HIV LTR. Using ACH-2 cells serially diluted in primary human PBMCs, we established the detection limit of this assay to be 2 HIV DNA copies $/ 1 \times 10^{5}$ cells. Quantitative reverse transcription polymerase chain reaction (qRT-PCR) amplification reactions for the HIV LTR were performed using six replicates of each DNA sample.

\section{Statistical analyses}

Data were analyzed using GraphPad Prism (v.6.0c for Mac; San Diego, CA). Mann-Whitney $U$-test was used for comparisons between groups, and Spearman's rank correlation test was used to determine associations among parameters. As this was an exploratory, hypothesis-generating study, there was no correction for multiple comparisons.

\section{Results}

\section{Study population}

We enrolled five participants who started ART during acute HIV-1 infection, five who started ART during chronic HIV infection, and five with chronic HIV-1 infection who were not taking ART (Table 1). The median age of all participants was 40 years (31 in the acute group, 45 in the chronic on ART group, and 26 in the chronic no ART group). Seven black non-Hispanic, three white non-Hispanic, and five Hispanic people were enrolled. The racial and ethnic distribution of the groups differed ( $p=.03$ by chi-square), with Hispanic people dominating the acute group and black people dominating the chronic no ART group. The median $\mathrm{CD}^{+} \mathrm{T}$ cell count at the time of recruitment was 823 (range $=555-1,051)$ cells $/ \mathrm{mm}^{3}$ with no significant differences among groups $(826[555-1,051]$ in acute, 819 [640970] in chronic on ART, and 782 [583-1,004] cells $/ \mathrm{mm}^{3}$ in chronic not on ART). The HIV-1 RNA levels at entry were $<20$ copies/mL in the acute and chronic on ART groups and $8,960(4,250-127,000)$ copies $/ \mathrm{mL}$ in the chronically infected without ART group. Median duration of ART was 6 (4-28) months in the acute group and 82 (11-142) months in the chronic group. Antiretroviral regimens are given in Table 1.

\section{Circulating CD4, Tscm, and NK cells}

First, we aimed to determine whether early ART affected $\mathrm{CD}^{+}{ }^{+} \mathrm{Tscm}$ and NK cells in circulation. We found no significant differences among groups in frequencies of $\mathrm{CD}^{+} \mathrm{T}$ cells $\left(\mathrm{CD}^{+} \mathrm{CD}^{+}\right), \mathrm{CD}^{+} \mathrm{Tscm}$, or $\mathrm{CD}^{+} \mathrm{Tscm}^{\text {(Supplementary }}$ Table S1). In addition, we found no significant differences among groups in the frequencies of NK cells overall $\left(\mathrm{CD}^{-} \mathrm{CD}^{-}\right.$lymphocytes that express $\mathrm{CD} 56$ and/or CD16) as a percentage of live cells or, within this population, in the

Table 1. Characteristics

\begin{tabular}{lcccc}
\hline & Overall & Acute on ART & Chronic on ART & Chronic no ART \\
\hline Age, years, median (range) & $40(19-55)$ & $31(26-47)$ & $45(40-52)$ & $26(19-55)$ \\
Race/ethnicity $(N)$ & 3 & 1 & 2 & 0 \\
White non-Hispanic & 5 & 4 & 0 & 1 \\
White Hispanic & 7 & 0 & 3 & 4 \\
Black non-Hispanic & $823(555-1,051)$ & $826(555-1,051)$ & $819(640-970)$ & $782(583-1,004)$ \\
CD4, cells $/ \mathrm{mm}^{3}$, median (range) & $<20$ & $<20$ & $<20$ & $8,960(4,250-127,000)$ \\
HIV-1 RNA, copies/mL, median (range) & $1.8(0.03-26.0)$ & $1.7(0.6-2.5)$ & $9.2(3.1-26.0)$ & $0.46(0.03-18.2)$ \\
Time since diagnosis, years, median (range) & & & & 0 \\
ART & 9 & 5 & 4 & 0 \\
NRTI & 4 & 1 & 3 & 0 \\
NNRTI & 6 & 1 & 3 & 0 \\
INSTI & 2 & 1 & \\
$\quad$ PI & $0.61(0.54-1.18)$ & $0.57(0.55-0.91)$ & $0.70(0.59-0.83)$ & $0.65(0.54-1.18)$ \\
CIMT, mm & & & &
\end{tabular}

ART, antiretroviral therapy; CIMT, carotid intima media thickness. 

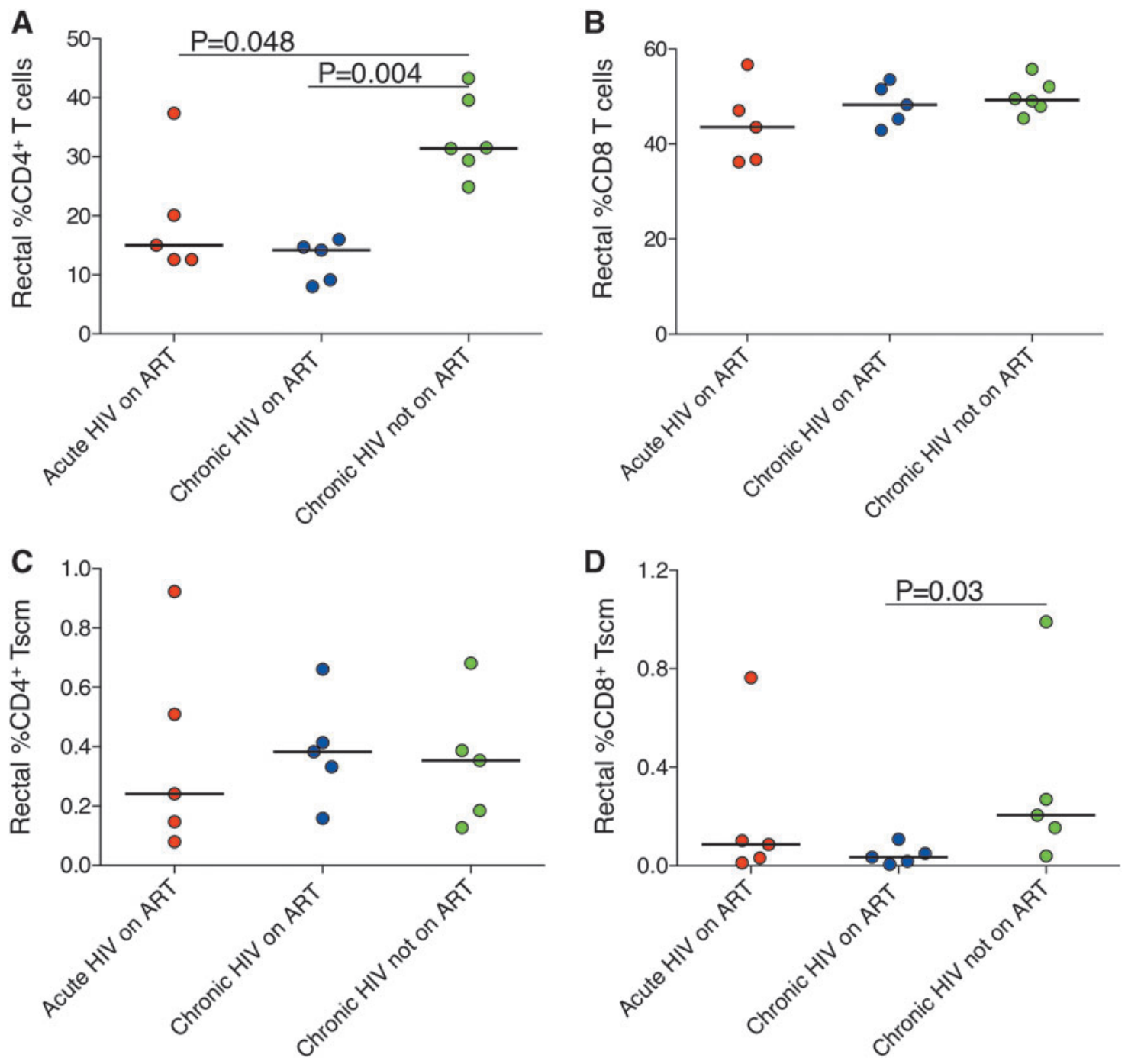

FIG. 1. (A) Frequency of rectal $\mathrm{CD} 4^{+} \mathrm{T}$ cells. (B) Frequency of rectal $\mathrm{CD} 8^{+} \mathrm{T}$ cells. (C) Frequency of rectal $\mathrm{CD} 4^{+} \mathrm{Tscm}$. (D) Frequency of rectal $\mathrm{CD} 8^{+} \mathrm{Tscm}$. Tscm, $\mathrm{T}$ memory stem cells.

frequencies of $\mathrm{CD} 56^{-} \mathrm{CD} 16^{\text {bright }}, \mathrm{CD} 56^{\text {bright }}, \mathrm{CD}^{\text {bright }} \mathrm{CD} 16-$ ${ }_{\text {dim }}, \mathrm{CD} 56^{\text {bright }} \mathrm{CD} 16^{-}, \mathrm{CD} 56^{\mathrm{dim}}$, or $\mathrm{CD} 56^{\text {dim }} \mathrm{CD} 16^{\text {bright }}$ cells (Supplementary Table S1).

\section{Rectal NK cells}

Next, we evaluated whether early ART affected $\mathrm{CD}^{+} \mathrm{T}$ cells, $\mathrm{CD}^{+}{ }^{+} \mathrm{Tscm}$, and NK cells in the rectum. We found, unexpectedly, a significantly lower frequency of rectal CD $4^{+}$ $\mathrm{T}$ cells in the group that started ART during acute infection (15.0\%, $p=.048)$ or chronic infection $(14.2 \%, p=.004)$ compared with the group not on ART (31.5\%; Fig. 1A), but no differences in rectal $\mathrm{CD}^{+} \mathrm{T}$ cells (Fig. 1B). We found no differences among groups in the frequencies of $\mathrm{CD}^{+} \mathrm{Tscm}$ (Fig. 1C). In contrast, we found that the group not on ART had a higher frequency of rectal $\mathrm{CD}^{+} \mathrm{Tscm}(0.21 \%)$ compared with the group that started ART in chronic infection $(0.03 \%, p=.03$; Fig. 1D).

In the rectum, there were no significant differences among groups in the frequencies of NK cells overall (Fig. 2A) or $\mathrm{CD}^{-} 6^{-} \mathrm{CD} 16^{\text {dim }}$ cells (Fig. 2C). Compared with the group with chronic HIV-1 not on ART, the group that started ART in chronic infection had lower rectal $\mathrm{CD} 56^{-} \mathrm{CD} 16^{\text {bright }}$ cell frequencies $(0.006 \%$ vs. $0.002 \%, p=.056$; Fig. 2B), CD56 ${ }^{\text {bright }}$ cells $(1.26 \%$ vs. $0.49 \%, p=.04$; Fig. $2 \mathrm{E})$, and CD56 ${ }^{\text {bright }} \mathrm{CD} 16^{-}$cells $(1.04 \%$ vs. $0.38 \%, p=.03$; Fig. $2 \mathrm{G})$, whereas the group that started ART in acute infection had lower CD56 $6^{\text {bright }}$ cell $(1.26 \%$ vs. $0.39 \%, p=.016$; Fig. 2E) and $\mathrm{CD} 56^{\text {bright }} \mathrm{CD}^{-}$cell $(1.04 \%$ vs. $0.33 \% ; p=.016$; Fig. 2G) frequencies. The group that started ART in acute infection also had lower CD56 ${ }^{\mathrm{dim}}(4.26 \%$ vs. $6.30 \%, p=.095$; Fig. 2D) and $\mathrm{CD}_{56} 6^{\text {bright }} \mathrm{CD} 16^{\mathrm{dim}}(0.014 \%$ vs. $0.087 \%$, $p=.02$; Fig. $2 \mathrm{~F}$ ) populations, although the former did not reach statistical significance.

\section{HIV-1 DNA $A^{+}$in $C D 4^{+} T$ cells}

We examined whether early ART affected the amount of HIV-1 DNA in circulating and rectal $\mathrm{CD}^{+} \mathrm{T}$ cells. We found that HIV-1 DNA levels were lower in circulating $\mathrm{CD}^{+}{ }^{+} \mathrm{T}$ cells in the group that started ART in acute infection compared with chronic on ART (221 vs. 1,527 copies $/ 10^{6} \mathrm{CD}^{+} \mathrm{T}$ 

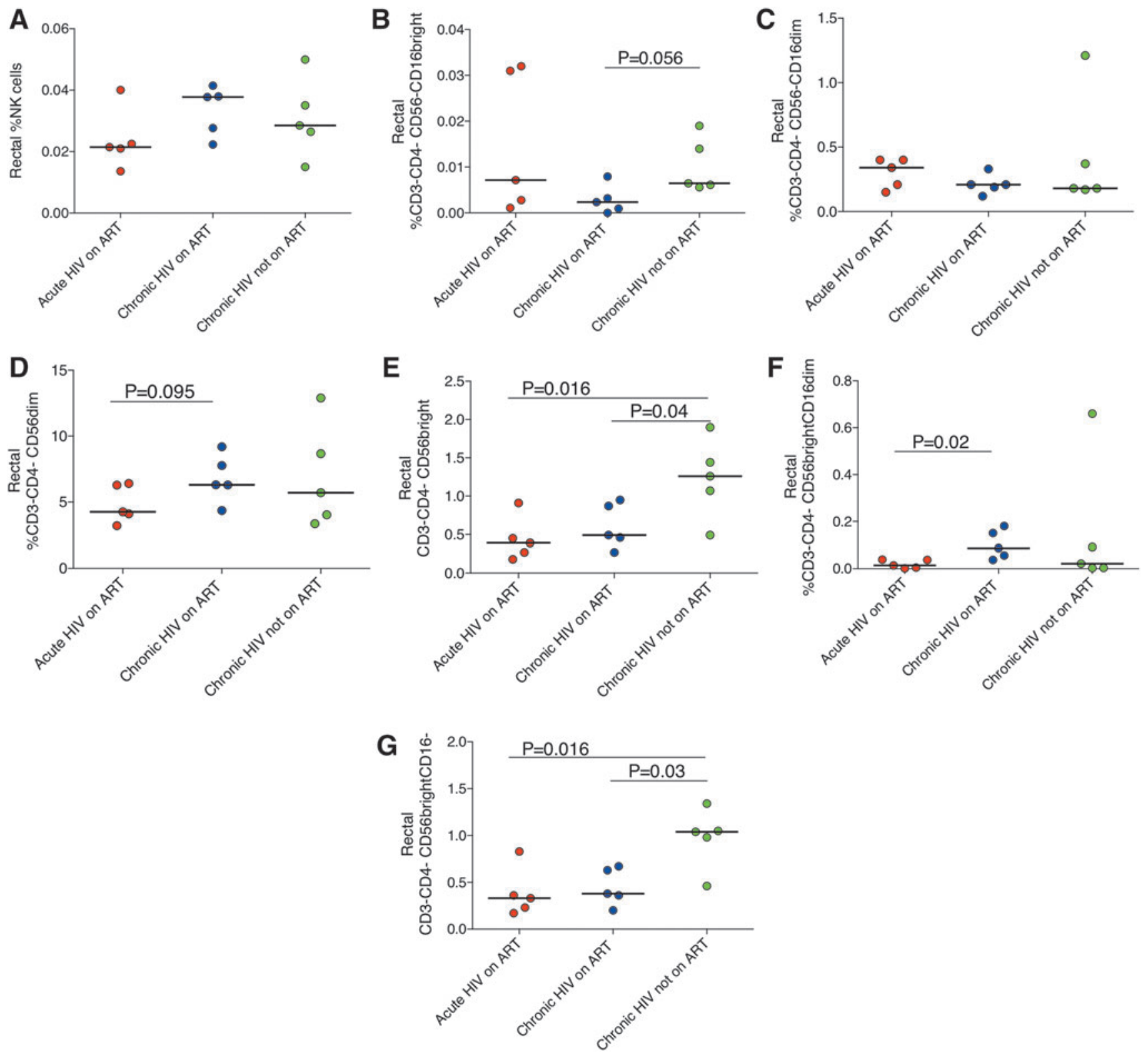

FIG. 2. Frequency of rectal NK cell populations. (A) Frequency of rectal NK cells as a percentage of live cells. (B) Frequency of rectal $\mathrm{CD}^{-} 6^{-} \mathrm{CD} 16^{\text {bright }}$ cells as a percentage of live $\mathrm{CD} 3^{-} \mathrm{CD} 4^{-}$cells. (C) Frequency of rectal CD56 ${ }^{-}$CD16 ${ }^{\text {dim }}$ cells. (D) Frequency of rectal CD56 $6^{\text {dim }}$ cells. (E) Frequency of rectal CD56 ${ }^{\text {bright }}$ cells. (F) Frequency of rectal CD56 ${ }^{\text {bright }} \mathrm{CD} 16^{\text {dim }}$ cells. (G) Frequency of rectal CD56 ${ }^{\text {bright }} \mathrm{CD} 16^{-}$cells. NK, natural killer.

cells; $p=.056$; Fig. 3A) with similar findings in the rectum (<20 vs. 8,133 copies $/ 10^{6} \mathrm{CD}^{+}$T cells; $p=.095$; Fig. 3B). In addition, HIV-1 DNA levels were lower in rectal $\mathrm{CD}^{+}{ }^{+} \mathrm{T}$ cells in the group that started ART in acute infection compared with chronic without ART (<20 vs. 8,257 copies $/ 10^{6}$ $\mathrm{CD}^{+} \mathrm{T}$ cells; $p=.095$; Fig. 3B). Thus, early initiation of ART may decrease the HIV-1 DNA levels in both peripheral blood and gut.

\section{Carotid intima media thickness}

To determine whether cardiovascular risk was affected by the timing of ART initiation or by these cell populations, we quantified carotid intima media thickness (CIMT). We found no differences across groups in CIMT $(0.57 \mathrm{~mm}$ in acute on ART, $0.70 \mathrm{~mm}$ in chronic on ART, $0.65 \mathrm{~mm}$ in chronic without ART; Table 1), suggesting early ART does not affect cardiovascular risk based on this small group of participants.

\section{Associations}

To explore the relevance of these findings, we determined correlations among the cell populations, HIV-1 DNA reservoir and $\mathrm{CD}^{+} \mathrm{T}$ cells. We found that higher amounts of HIV-1 DNA in rectal $\mathrm{CD}^{+} \mathrm{T}$ cells were associated with higher frequencies of circulating $\mathrm{NK}(r=0.75, p=.002$; Fig. 3C), $\mathrm{CD}^{-} 6^{-} \mathrm{CD} 6^{\text {bright }}\left(r=0.58, p=.03\right.$; Fig. 3D), CD56 $^{\text {dim }}(r=0.72$, $p=.003$; Fig. 3E), and CD56 ${ }^{\text {dim }} \mathrm{CD} 16^{\text {bright }}(r=0.75, p=.002$; 

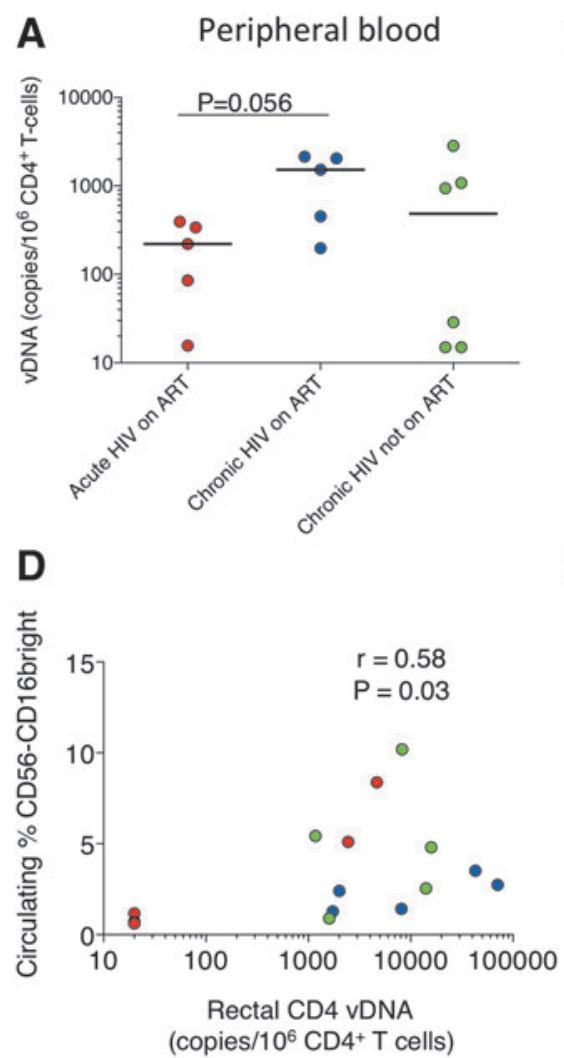

- Acute HIV on ART

- Chronic HIV on ART

- Chronic HIV not on ART

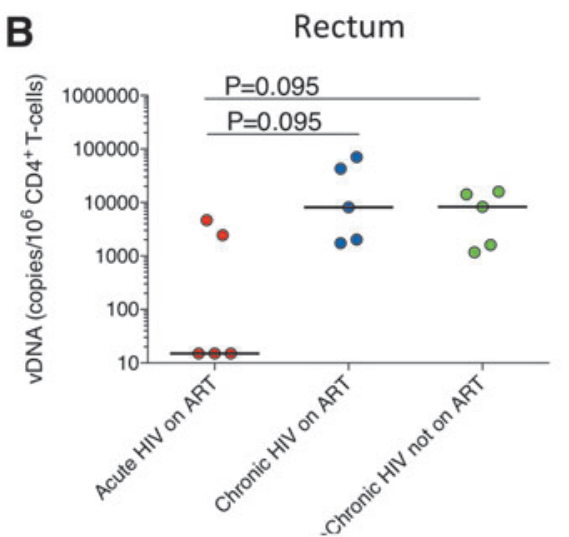

C

E

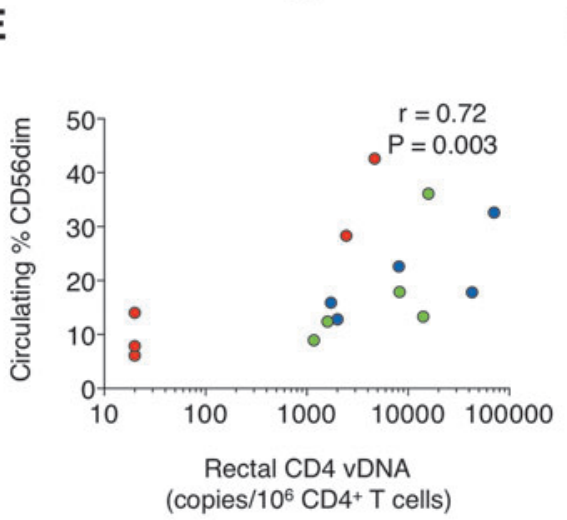

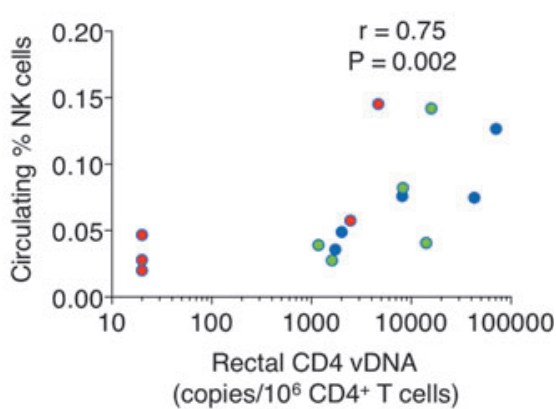

$\mathbf{F}$

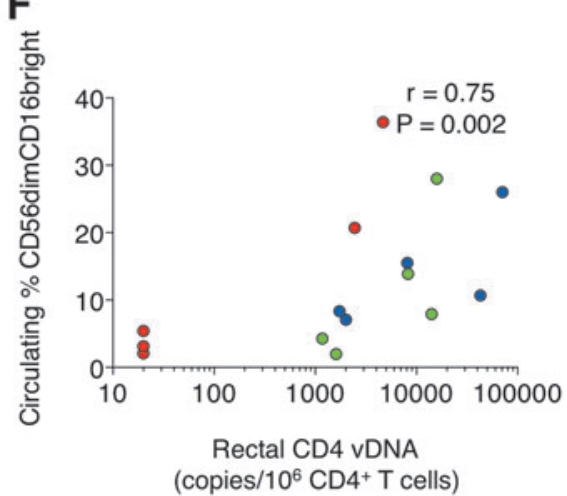

FIG. 3. Cell-associated HIV-1 DNA. (A) HIV-1 DNA levels in circulating CD4 ${ }^{+}$T cells. (B) HIV-1 DNA levels in rectal $\mathrm{CD}^{+}{ }^{+} \mathrm{T}$ cells. (C) Association of circulating NK cells with rectal HIV-1 DNA in CD4 ${ }^{+} \mathrm{T}$ cells. (D) Association of circulating CD56 ${ }^{-}$D16 $6^{\text {bright }}$ cells with rectal HIV-1 DNA in $\mathrm{CD}^{+}{ }^{+}$T cells. (E) Association of circulating CD56 ${ }^{\text {dim }}$ cells with rectal HIV-1 DNA in CD4 ${ }^{+}$T cells. (F) Association of CD56 ${ }^{\text {dim }}{ }^{2}$ 16 $6{ }^{\text {bright }}$ cells with rectal HIV-1 DNA in CD4 ${ }^{+}$T cells. Red circles represent participants who started ART in acute HIV infection, blue circles represent participants who started ART in chronic HIV infection, and green circles represent participants with chronic HIV infection not taking ART. ART, antiretroviral therapy.

Fig. 3F) cells. We found that higher current $\mathrm{CD} 4^{+} \mathrm{T}$ cell counts were associated with higher frequencies of rectal NK cells $(r=0.54, p=.04 ;$ Fig. $4 \mathrm{~A})$ and rectal $\mathrm{CD} 56^{\text {bright }} \mathrm{CD} 16^{\mathrm{dim}}$ $(r=0.53, p=.046$; Fig. $4 \mathrm{~B})$ and CD56 ${ }^{\mathrm{dim}} \mathrm{CD} 16^{\text {bright }}(r=0.60$, $p=.02$; Fig. 4C) cells. We also found that higher circulating nadir $\mathrm{CD}^{+} \mathrm{T}$ cell counts were associated with higher frequencies of rectal CD56 $6^{\text {bright }}(r=0.71, p=.008$; Supplementary Fig. S3A) and CD56 ${ }^{\text {bright }}$ CD16 cells $(r=0.66, p=.017$; Supplementary Fig. S3B).

Higher circulating $\mathrm{CD}^{+}$Tscm frequencies were associated with higher frequencies of circulating $\mathrm{CD}^{+}$Tscm $\left(r=0.61, p=.018\right.$; Supplementary Fig. S4A) and rectal CD4 ${ }^{+}$ Tscm $(r=0.63, p=.01$; Supplementary Fig. S4B) and lower frequencies of circulating NK cells $(r=-0.69, p=.006$; Supplementary Fig. S4C) but not with $\mathrm{CD}^{+}{ }^{+} \mathrm{HIV}-1$ DNA levels. Higher circulating $\mathrm{CD}^{+}{ }^{+} \mathrm{Tscm}$ frequencies were also associated with lower circulating NK cell $(r=-0.56, p=.03$; Supplementary Fig. S4D) and higher rectal CD4 Tscm $(r=0.61, p=.017$; Supplementary Fig. S4E) frequencies. Higher frequencies of rectal $\mathrm{CD}^{+}{ }^{+} \mathrm{Tscm}$ were associated with lower frequencies of circulating CD56 ${ }^{\mathrm{dim}}(r=-0.57$, $p=.03$; Supplementary Fig. S5A) and CD56 ${ }^{\mathrm{dim}} \mathrm{CD} 16^{\text {bright }}$ $(r=-0.53, p=.047$; Supplementary Fig. S5B) cells and higher rectal $\mathrm{CD}^{+}$Tscm frequencies $(r=0.57, p=.03$; Supplementary Fig. S5C). Higher frequencies of rectal CD8 ${ }^{+}$ Tscm were associated with lower circulating CD4-associated vDNA levels $(r=-0.52, p=.05$; Fig. 4C) and higher frequencies of rectal CD $4^{+}$T cells $(r=0.64, p=.01 ;$ Fig. 4D) and rectal CD56 ${ }^{\text {bright }}(r=0.58, p=.02$; Supplementary Fig. S5D), $\mathrm{CD} 6^{\text {bright }} \mathrm{CD} 16^{-}(r=0.58, p=.03$; Supplementary Fig. S5E $)$, and $\mathrm{CD}^{-} 6^{-} \mathrm{CD} 16^{\text {bright }} \quad(r=0.56, \quad p=.03 ; \quad$ Supplementary Fig. S5F) cells.

Older age was associated with higher frequencies of rectal $\mathrm{CD} 6^{\text {bright }} \mathrm{CD} 16^{\mathrm{dim}} \quad(r=0.78, \quad p=.001 ; \quad$ Supplementary Fig. S6A) and CD56 ${ }^{\mathrm{dim}} \mathrm{CD} 16^{\text {bright }}(r=0.62, p=0.015$; Supplementary Fig. S6B) cells and higher CIMT values $(r=0.91$, $p<.0001$; Supplementary Fig. S6C), and higher CIMT values were also associated with higher frequencies of rectal CD56 ${ }^{\text {bright }} C D 16^{\text {dim }}$ cells $(r=0.69, p=.008$; Supplementary Fig. S6D) and rectal CD56 ${ }^{\mathrm{dim}} \mathrm{CD} 16^{\text {bright }}$ cells $(r=0.56$, $p=.04$; Supplementary Fig. S6E). In summary, a larger rectal HIV reservoir was associated with greater frequencies of 

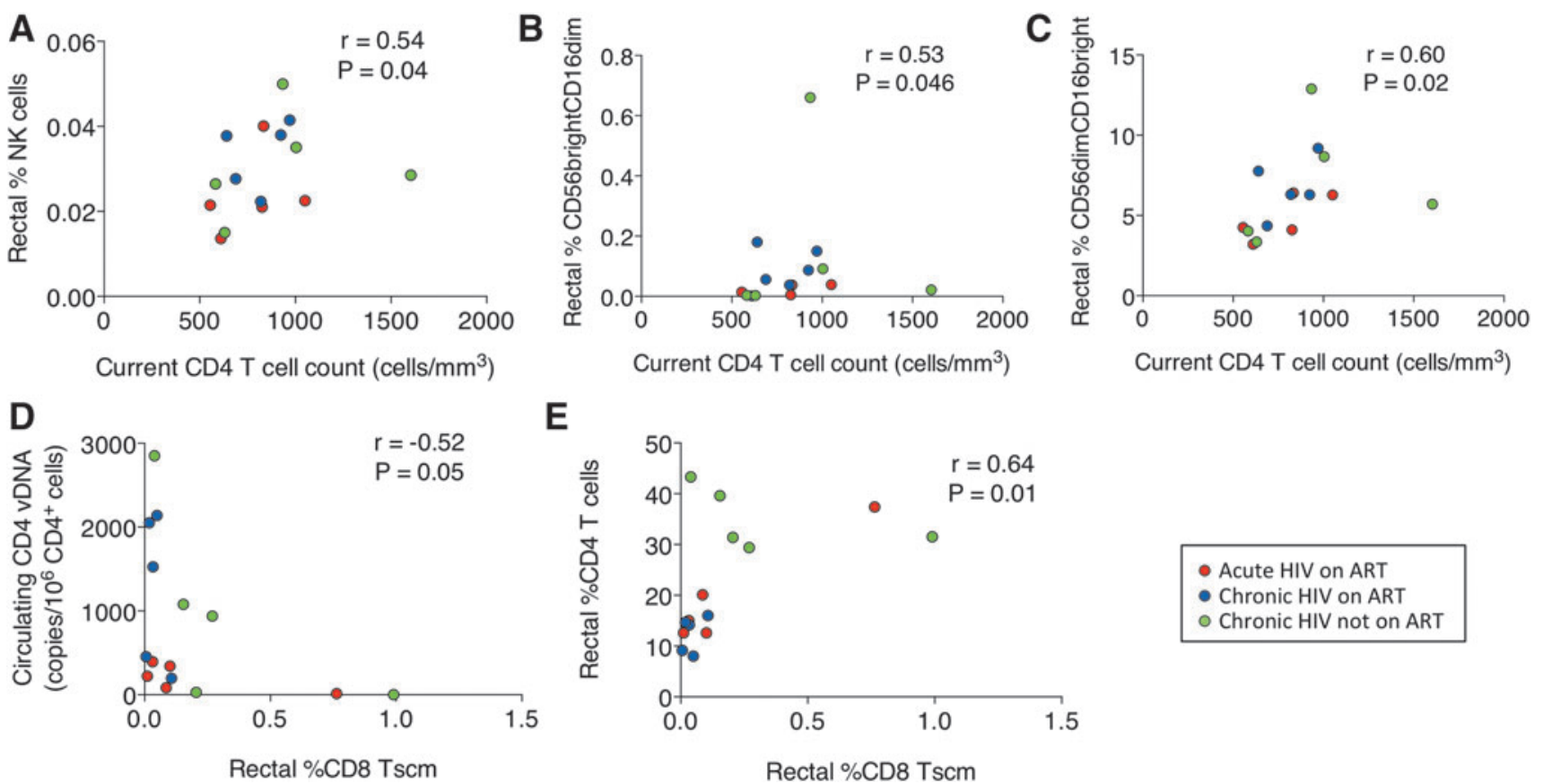

- Acute HIV on ART

- Chronic HIV on ART

- Chronic HIV not on ART

FIG. 4. Association of circulating $\mathrm{CD} 4^{+} \mathrm{T}$ cells with $(\mathbf{A})$ rectal NK cells. (B) $\mathrm{CD} 56^{\text {bright }} \mathrm{CD} 16^{\text {dim }}$ cells. (C) $\mathrm{CD} 56^{\text {dim }} \mathrm{CD} 16^{\text {bright }}$ cells. Association of rectal $\mathrm{CD}^{+}{ }^{+} \mathrm{Tscm}_{\text {with }}(\mathbf{D})$ circulating CD4-associated HIV-1 DNA and (E) rectal CD4 ${ }^{+} \mathrm{T}$ cells. Red circles represent participants who started ART in acute HIV infection, blue circles represent participants who started ART in chronic HIV infection, and green circles represent participants with chronic HIV infection not taking ART.

circulating NK cells; higher current $\mathrm{CD}^{+}{ }^{+} \mathrm{T}$ cell counts were associated with higher frequencies of rectal NK cells; rectal CD56 ${ }^{\text {bright }} \mathrm{CD} 16^{\mathrm{dim}}$ and $\mathrm{CD} 56^{\mathrm{dim}} \mathrm{CD} 16^{\text {bright }} \mathrm{NK}$ cells were associated with higher cardiovascular risk; and rectal $\mathrm{CD}^{+}$ Tscm were associated with a smaller circulating reservoir and more rectal $\mathrm{CD} 4^{+} \mathrm{T}$ cells.

\section{Discussion}

In this study, we aimed to determine how peripheral blood and gut NK cells, Tscm cells, and HIV-1 DNA varied across people who started ART in acute infection, people who started ART in chronic infection, and people not taking ART. We found that (1) the group that started ART in acute infection had significantly lower rectal CD56 $6^{\text {bright }} C D 16^{\text {dim }}$ cell frequencies compared with the group that started on ART in chronic HIV infection and lower rectal CD56 $6^{\text {bright }}$ and $\mathrm{CD} 6^{\text {bright }} \mathrm{CD} 16^{-}$cell frequencies compared with the group with chronic HIV infection not on ART; (2) the group that was not taking ART had higher rectal $\mathrm{CD} 56^{-} \mathrm{CD} 16^{\text {bright }}$, CD56 $6^{\text {bright }}$, and $\mathrm{CD} 56^{\text {bright }} \mathrm{CD} 16^{-}$cell frequencies than the group with chronic HIV on ART; (3) HIV-1 DNA levels tended to be lower in circulating and rectal $\mathrm{CD} 4^{+} \mathrm{T}$ cells in the group that started ART in acute infection compared with the group that started ART in chronic infection; (4) higher levels of HIV-1 DNA in rectal $\mathrm{CD}^{+}{ }^{+} \mathrm{T}$ cells were associated with higher frequencies of circulating NK cells, including $\mathrm{CD}^{-} 6^{-} \mathrm{CD} 16^{\text {bright }}, \mathrm{CD}^{\mathrm{dim}}{ }^{\mathrm{dim}}$, and $\mathrm{CD} 56^{\mathrm{dim}} \mathrm{CD} 16^{\text {bright }} \mathrm{NK}$ cells; and (5) rectal $\mathrm{CD}^{+} \mathrm{Tscm}$ frequencies were higher in the group not on ART compared with the chronic group on ART with no differences in circulating or rectal $\mathrm{CD}^{+}{ }^{+} \mathrm{Tscm}$ populations. Thus, the timing of ART initiation determines rectal NK cell populations, and the use of ART can influence rectal $\mathrm{CD}^{+}$Tscm populations.

In acute HIV-1 infection, NK cells are activated and proliferate. ${ }^{19} \mathrm{HIV}$-infected cells stimulate NK cell-mediated lysis by downregulating inhibitory receptors on NK cells and stimulating the activating NKG2D receptor; the ensuing lysis of the infected cell thereby inhibits viral replication and the chemokine production blocks virus entry by blocking CCR5 ${ }^{20}$ NK cells are essential for HIV-1 control. ${ }^{20}$

The majority of circulating $\mathrm{NK}$ cells are CD56 ${ }^{\mathrm{dim}} \mathrm{NK}$ cells, which express perforin and granzyme B and are cytotoxic. ${ }^{9,21}$ CD56 ${ }^{\text {bright }} \mathrm{NK}$ cells have limited cytotoxic capacity but produce copious cytokines such as IFN- $\gamma$ and tumor necrosis factor. ${ }^{22}$ CD56 $6^{\text {bright }} \mathrm{NK}$ cells contract in peripheral blood and expand in the gut and CD56 ${ }^{\mathrm{dim}} \mathrm{CD} 16^{+}$cells expand in the periphery in acute HIV-1 infection. ${ }^{9,20,23}$ In addition, a subset of $\mathrm{CD}^{2} 6^{\mathrm{dim}} \mathrm{CD} 16^{+}$cells expressing $\mathrm{CD} 11 \mathrm{~b}$ and CD161 but not CD57 or Siglec-7 may contribute to virologic control, potentially by a higher frequency of degranulation, as they are more common in elite controllers than viremic persons. ${ }^{24}$ The correlation of higher frequencies of CD56 ${ }^{\mathrm{dim}} \mathrm{CD} 16^{\text {bright }}$ cells in the rectal tissue with higher circulating $\mathrm{CD}^{+} \mathrm{T}$ cell counts in our study would be consistent with this hypothesis. As this population also correlates with a higher rectal HIV-1 reservoir, it is tempting to speculate that these populations are responding to the increased reservoir. Thus, in acute infection, NK cell subsets that may control viral replication expand. Recent data indicate that CD56 ${ }^{\text {bright }} \mathrm{NK}$ cells in tissues can be antigen specific, raising the question of whether the expansion of this population in the gut may be responding to HIV and inducing local inflammation. ${ }^{25}$ Indeed, the frequency of rectal 
CD56 ${ }^{\text {bright }} \mathrm{NK}$ cells was higher in the group that was not taking ART compared with the groups taking ART, suggesting that their presence may be stimulated by ongoing HIV replication.

Of note, perforin and Ki67 expression are higher in lymph node NK cells in acute simian immunodeficiency virus (SIV) compared with chronic SIV infection, suggesting increased degranulation and turnover in acute infection. ${ }^{20}$ $\mathrm{CD}^{\mathrm{dim}}{ }^{\mathrm{dim}} \mathrm{CD} 16^{+}$and CD56 ${ }^{\text {bright }}$ cells subsequently decrease in chronic HIV-1 infection, ${ }^{19,21}$ whereas $\mathrm{CD} 56^{-} \mathrm{CD} 16^{+}$cells emerge and accumulate in the periphery and the lymph node. ${ }^{10,19,20,26}$

Indeed, $\mathrm{CD} 56^{-} \mathrm{CD} 16^{\text {bright }}$ cells are rare in the absence of disease, ${ }^{10,22}$ but $\mathrm{CD} 56^{-} \mathrm{CD} 16^{+} \mathrm{NK}$ cells are increased in viremic persons compared with HIV-negative controls. ${ }^{24}$ Consistent with this observation, we found that this population tended to be higher in the rectum of people who were not taking ART compared with those who initiated ART in chronic HIV-1 infection.

"Dysfunctional" or "exhausted" CD56 ${ }^{-} \mathrm{CD} 16^{+/ \text {bright }}$ cells, which correlated with rectal CD4-associated HIV-1 DNA, expand in the setting of continued HIV-1 replication, ${ }^{9}$ and their frequency is three times higher in SIV-infected compared with SIV-uninfected rhesus macaques. ${ }^{20} \mathrm{CD} 56^{-} \mathrm{CD} 16^{+}$cells are terminally differentiated cells ${ }^{21}$ that have fewer activating and more inhibitory receptors. ${ }^{22}$ Thus, $\mathrm{CD} 56^{-} \mathrm{CD} 16^{+}$cells are ineffective, or at least less effective, at cytotoxicity and producing cytokines and chemokines including CCR5 ligands (CCL3, CCL4, and CCL5), ${ }^{9,27}$ and some propose that their expansion, replacing more functional cells, may facilitate HIV-1 infection of CD $4^{+}$T cells. ${ }^{9}$ Of note, $\mathrm{CD} 56^{-} \mathrm{CD} 16^{+} \mathrm{NK}$ cells can suppress IFN- $\gamma$ production by $\mathrm{CD}^{+}{ }^{\mathrm{T}}$ cells. ${ }^{28}$ Indeed, high plasma viral load is associated with higher frequencies of $\mathrm{CD}^{2} 6^{-} \mathrm{CD} 16^{+}$cells. $^{29}$

On the contrary, the presence of these cells may reflect recent degranulation of more functional cells. $\mathrm{CD}^{-} 6^{-} \mathrm{CD} 16^{+}$ cells express less granzyme B and perforin compared with other NK cells, and CD95 expression is upregulated to a greater extent on $\mathrm{CD}^{-} 6^{-} \mathrm{CD} 16^{+}$cells compared with $\mathrm{CD}^{2} 6^{+} \mathrm{CD} 16^{+}$cells in people with HIV, suggesting recent target cell engagement. ${ }^{22} \mathrm{CD} 56^{-} \mathrm{CD} 16^{+}$cells from people with HIV-1 produce more IFN- $\gamma$ than people without HIV at baseline, suggesting they are activated, but do not respond significantly to stimulation. ${ }^{22}$

The decreased frequency of CD56 $6^{\text {bright }}$ cells, the major cytokine producers, in people who were taking ART, may result in less local cytokine production, which could limit NK and $\mathrm{CD}^{+} \mathrm{T}$ cell activation and compromise virus control if ART were stopped. ${ }^{30,31}$ Alternatively, the decreased cytokine production could lead to less local inflammation to stimulate HIV-1 replication and help preserve $\mathrm{CD} 4^{+} \mathrm{T}$ cells. ${ }^{30-32}$ As noted previously, NK cells, particularly CD $56^{\text {bright }}$ NK cells, accumulate within atherosclerotic lesions,${ }^{12}$ and participants with higher CIMT in our study had higher frequencies of rectal CD56 ${ }^{\text {bright }} \mathrm{CD} 16^{\mathrm{dim}}$ cells. The rectal cells may contribute to higher CIMT, or they could reflect an overall increase in this population in tissues, including the vasculature. We did not have sufficient samples to further characterize CD56 $6^{\text {bright }}$ cells, such as by evaluating NK cell receptors or surface markers such as CD11b and CD161 that distinguish subsets of CD56 bright cells that differentiate viremic from treated people with HIV. ${ }^{24}$
The inverse association of rectal CD4 Tscm with circulating cytotoxic NK cells raises the question of whether these CD4 Tscm persist because of insufficient control by NK cells. In contrast, the direct association of rectal CD8 Tscm with rectal cytokine-producing and cytotoxic NK cells may reflect an overall environment supporting HIV-1 control. The association of higher rectal $\mathrm{CD} 8^{+} \mathrm{Tscm}$ frequencies with lower amounts of HIV-1 DNA in $\mathrm{CD}^{+} \mathrm{T}$ cells is consistent with this postulation. Higher frequencies of rectal $\mathrm{CD} 8^{+} \mathrm{Tscm}$ in the group not on ART could reflect that this population was relatively healthy as they retained a median $\mathrm{CD} 4^{+} \mathrm{T}$ cell count of 782 cells $/ \mathrm{mm}^{3}$ despite the absence of ART. Four of these five participants had been diagnosed in the previous year (three of whom were 26 years of age or younger) and may be in the early stages of infection; the fifth participant was diagnosed more than 18 years before enrollment and had HIV-1 RNA of 4,250 copies/mL, suggesting the participant was a long-term nonprogressor. A larger number of participants may be needed to elucidate whether there are differences across these three populations.

Previous studies observed lower HIV-1 DNA levels in blood and rectal $\mathrm{CD} 4^{+} \mathrm{T}$ cells of participants starting ART in early/acute infection compared with those starting ART in chronic infection ${ }^{33,34}$ Furthermore, the level of HIV-1 DNA in rectal $\mathrm{CD}^{+} \mathrm{T}$ cells tended to be higher than in $\mathrm{CD}^{+} \mathrm{T}$ cells from blood. ${ }^{33-35}$ Our results are largely in agreement with these studies, and others ${ }^{16,33,34,36,37}$ for participants who initiated ART during acute infection. Differences may be because of the small study size and the relative timing of ART initiation during acute/early infection.

This study has several limitations. First, the sample size in each group was small, which may have prevented us from discovering other differences across groups. Second, the cell yield of rectal biopsies did not permit more than one flow cytometry panel to be performed, limiting the degree to which we could characterize the cells. Thus, by simultaneously quantifying NK cell and T cell markers on the limited samples we had, we could not thoroughly characterize either cell type. Third, the groups were not matched on age, sex, race, duration of infection, and for the treated groups, duration of ART, which may have confounded our results. Fourth, the chronic HIV not on ART group may not have progressed to the same stage of disease as the chronic on ART group. Fifth, we performed multiple comparisons on a small sample size, increasing our chances of a type I error.

In summary, we found that rectal NK cell populations differed based on whether ART was initiated in acute or chronic infection, or not at all, and correlated with circulating $\mathrm{CD} 4^{+} \mathrm{T}$ cell count, whereas higher circulating NK cell frequencies were associated with higher levels of HIV-1 DNA in rectal $\mathrm{CD} 4^{+} \mathrm{T}$ cells. Together, these findings suggest an evolution of NK cell populations during the course of infection, but residual HIV-1 in the gut may contribute to systemic NK cell activation.

\section{Author Disclosure Statement}

No competing financial interests exist.

\section{Funding Information}

NIH grant AI1116167 to J.T.K and NIH grant 5P30AI036211-18 to K.J.V. This project was supported by 
the Cytometry and Cell Sorting Core at Baylor College of Medicine with funding from the CPRIT Core Facility Support Award (CPRIT-RP180672), the NIH (CA125123 and RR024574) and the assistance of Joel M. Sederstrom.

\section{Supplementary Material}

Supplementary Figure S1

Supplementary Figure S2

Supplementary Figure S3

Supplementary Figure S4

Supplementary Figure S5

Supplementary Figure S6

Supplementary Table S1

\section{References}

1. Krebs SJ, Ananworanich J: Immune activation during acute HIV infection and the impact of early antiretroviral therapy. Curr Opin HIV AIDS 2016;11:163-172.

2. Robb ML, Ananworanich J: Lessons from acute HIV infection. Curr Opin HIV AIDS 2016;11:555-560.

3. Gattinoni L, Speiser DE, Lichterfeld M, Bonini C: T memory stem cells in health and disease. Nat Med 2017;23: 18-27.

4. Lugli E, Dominguez MH, Gattinoni L, et al.: Superior T memory stem cell persistence supports long-lived $\mathrm{T}$ cell memory. J Clin Invest 2013;123:594-599.

5. Ribeiro SP, Milush JM, Cunha-Neto E, et al.: The CD8(+) memory stem $\mathrm{T}$ cell $(\mathrm{T}(\mathrm{SCM}))$ subset is associated with improved prognosis in chronic HIV-1 infection. J Virol 2014;88:13836-13844.

6. Taborda NA, Gonzalez SM, Alvarez CM, Correa LA, Montoya CJ, Rugeles MT: Higher frequency of NK and CD4+ T-cells in mucosa and potent cytotoxic response in HIV controllers. PLoS One 2015;10:e0136292.

7. Meier UC, Owen RE, Taylor E, et al:: Shared alterations in NK cell frequency, phenotype, and function in chronic human immunodeficiency virus and hepatitis $\mathrm{C}$ virus infections. J Virol 2005;79:12365-12374.

8. Smyth MJ, Nutt SL: IL-7 and the thymus dictate the NK cell 'labor market'. Nat Immunol 2006;7:1134-1136.

9. Mikulak J, Oriolo F, Zaghi E, Di Vito C, Mavilio D: Natural killer cells in HIV-1 infection and therapy. AIDS 2017;31:2317-2330.

10. Scully E, Alter G: NK cells in HIV disease. Curr HIV/AIDS Rep 2016;13:85-94.

11. Sips M, Sciaranghella G, Diefenbach T, et al: : Altered distribution of mucosal NK cells during HIV infection. Mucosal Immunol 2012;5:30-40.

12. Bonaccorsi I, Spinelli D, Cantoni C, et al.: Symptomatic carotid atherosclerotic plaques are associated with increased infiltration of natural killer (NK) cells and higher serum levels of NK activating receptor ligands. Front Immunol 2019;10:1503.

13. Parisi L, Bassani B, Tremolati M, Gini E, Farronato G, Bruno A: Natural killer cells in the orchestration of chronic inflammatory diseases. J Immunol Res 2017;2017: 4218254.

14. Shah ASV, Stelzle D, Lee KK, et al:: Global burden of atherosclerotic cardiovascular disease in people living with HIV. Circulation 2018;138:1100-1112.

15. Sandler NG, Bosinger SE, Estes JD, et al.: Type I interferon responses in rhesus macaques prevent SIV infection and slow disease progression. Nature 2014;511:601-605.
16. Ananworanich J, Chomont N, Eller LA, et al.: HIV DNA set point is rapidly established in acute HIV infection and dramatically reduced by early ART. EBioMedicine 2016; 11:68-72.

17. Chahroudi A, Silvestri G, Lichterfeld M: T memory stem cells and HIV: A long-term relationship. Curr HIV/AIDS Rep 2015;12:33-40.

18. Chun TW, Murray D, Justement JS, et al.: Relationship between residual plasma viremia and the size of HIV proviral DNA reservoirs in infected individuals receiving effective antiretroviral therapy. J Infect Dis 2011;204:135138.

19. Nabatanzi R, Cose S, Joloba M, Jones SR, Nakanjako D: Effects of HIV infection and ART on phenotype and function of circulating monocytes, natural killer, and innate lymphoid cells. AIDS Res Ther 2018;15:7.

20. Schafer JL, Li H, Evans TI, Estes JD, Reeves RK: Accumulation of cytotoxic CD16+ NK cells in simian immunodeficiency virus-infected lymph nodes associated with in situ differentiation and functional anergy. J Virol 2015; 89:6887-6894.

21. Hong HS, Ahmad F, Eberhard JM, et al.: Loss of CCR7 expression on CD56(bright) NK cells is associated with a CD56(dim)CD16(+) NK cell-like phenotype and correlates with HIV viral load. PLoS One 2012; 7:e44820.

22. Milush JM, Long BR, Snyder-Cappione JE, et al:: Functionally distinct subsets of human NK cells and monocyte/ DC-like cells identified by coexpression of CD56, CD7, and CD4. Blood 2009; 114:4823-4831.

23. Holzemer A, Garcia-Beltran WF, Altfeld M: Natural killer cell interactions with classical and non-classical human leukocyte antigen class I in HIV-1 infection. Front Immunol 2017;8:1496.

24. Pohlmeyer CW, Gonzalez VD, Irrinki A, et al.: Identification of NK cell subpopulations that differentiate HIVinfected subject cohorts with diverse levels of virus control. J Virol 2019;93:e01790-18.

25. Nikzad R, Angelo LS, Aviles-Padilla K, et al.: Human natural killer cells mediate adaptive immunity to viral antigens. Sci Immunol 2019;4:eaat8116.

26. Florez-Alvarez L, Hernandez JC, Zapata W: NK cells in HIV-1 infection: From basic science to vaccine strategies. Front Immunol 2018;9:2290.

27. Voigt J, Malone DFG, Dias J, et al: : Proteome analysis of human CD56(neg) NK cells reveals a homogeneous phenotype surprisingly similar to CD56(dim) NK cells. Eur J Immunol 2018;48:1456-1469.

28. Ma M, Yin X, Zhao X, et al.: CD56(-) CD16(+) NK cells from HIV-infected individuals negatively regulate IFNgamma production by autologous CD8(+) T cells. J Leukoc Biol 2019;106:1313-1323.

29. Gregson JN, Kuri-Cervantes L, Mela CM, Gazzard BG, Bower M, Goodier MR: Short communication: NKG2C+ NK cells contribute to increases in CD16+CD56- cells in HIV type 1+ individuals with high plasma viral load. AIDS Res Hum Retroviruses 2013;29:84-88.

30. Roff SR, Noon-Song EN, Yamamoto JK: The significance of interferon-gamma in HIV-1 pathogenesis, therapy, and prophylaxis. Front Immunol 2014;4:498.

31. Pasquereau S, Kumar A, Herbein G: Targeting TNF and TNF receptor pathway in HIV-1 infection: From immune activation to viral reservoirs. Viruses 2017;9:E64.

32. Tabb B, Morcock DR, Trubey CM, et al:: Reduced inflammation and lymphoid tissue immunopathology in rhesus 
macaques receiving anti-tumor necrosis factor treatment during primary simian immunodeficiency virus infection. J Infect Dis 2013;207:880-892.

33. Eriksson S, Graf EH, Dahl V, et al.: Comparative analysis of measures of viral reservoirs in HIV-1 eradication studies. PLoS Pathog 2013;9:e1003174.

34. Josefsson L, von Stockenstrom S, Faria NR, et al:: The HIV-1 reservoir in eight patients on long-term suppressive antiretroviral therapy is stable with few genetic changes over time. Proc Natl Acad Sci U S A 2013;110:E4987E4996.

35. Khoury G, Fromentin R, Solomon A, et al.: Human immunodeficiency virus persistence and T-cell activation in blood, rectal, and lymph node tissue in human immunodeficiency virus-infected individuals receiving suppressive antiretroviral therapy. J Infect Dis 2017;215:911-919.

36. Jain V, Hartogensis W, Bacchetti P, et al.: Antiretroviral therapy initiated within 6 months of HIV infection is as- sociated with lower T-cell activation and smaller HIV reservoir size. J Infect Dis 2013;208:1202-1211.

37. Luo L, Wang N, Yue Y, et al.: The effects of antiretroviral therapy initiation time on HIV reservoir size in Chinese chronically HIV infected patients: A prospective, multi-site cohort study. BMC Infect Dis 2019;19:257.

Address correspondence to: Netanya S. Utay

Division of General Medicine Department of Internal Medicine McGovern Medical School

UT Health Science Center at Houston 6431 Fannin Street, MSB 1.122

Houston, TX 77030

E-mail: netanya.s.utay@uth.tmc.edu 